\title{
Pengaruh Penerapan E-Learning Terhadap Hasil Belajar Mahasiswa Informatika Universitas Dehasen Bengkulu
}

\author{
Hermawansa $^{\# 1}$

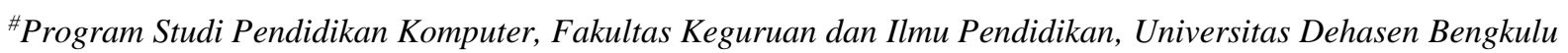 \\ Jl. Meranti Raya No. 32 Sawah Lebar Kota Bengkulu
}

1hermawansalunived.ac.id

\begin{abstract}
This research aims to determine the effect of e-learning on student learning outcomes in the Introduction to Information Technology (PTI) course in the Informatics Study Program, Faculty of Computer Science, Dehasen University Bengkulu. This research is a quasi experimental study in the form of pretest and posttest. The population was 60 students as a sample. Data obtained by documentation techniques and knowledge tests. The documentation technique is used to obtain data and information in the form of the number and student learning outcomes, while the knowledge test is given at the beginning (pre-test) and at the end (post-test) of the meeting. The collected data were analyzed using descriptive statistics. The analysis showed that the average student learning outcomes for the experimental class pre-test were 77.87 , with a standard deviation of 7.18. The average pre-test student learning outcomes for the control class were obtained 74.27 with a standard deviation of 7.02. While the post-test average student learning outcomes in the experimental class obtained 84.67 with a standard deviation of 7.51 and the average student learning outcomes for the control class were 80.93 with a standard deviation of 5.43. There is a significant difference in student learning outcomes in the introductory information technology course between groups treated using conventional methods and groups treated using E-Learning in the Informatics study program, Faculty of Computer Science, Dehasen University, Bengkulu.
\end{abstract}

Keywords,: E-Learning Effect,Learning outcomes

Abstrak - Penelitian ini bertujuan untuk mengetahui pengaruh e-learning terhadap hasil belajar mahasiswa pada mata kuliah Pengantar Teknologi Informasi (PTI) Program Studi Informatika Fakultas Ilmu Komputer Universitas Dehasen Bengkulu. Penelitian ini merupakan penelitian quasi experiment dalam bentuk Pretest dan posttest. Populasi berjumlah 60 orang mahasiswa sebagai sampel. Data diperoleh dengan teknik dokumentasi dan tes pengetahuan. Teknik dokumentasi digunakan untuk memperoleh data dan informasi berupa jumlah dan hasil belajar mahasiswa, sedangkan tes pengetahuan diberikan pada awal (pree tes) dan akhir (post tes) pertemuan. Data yang terkumpul dianalisis dengan menggunakan statistik deskriptif. hasil analisis menunjukkan bahwa rata-rata hasil belajar mahasiswa untuk pre-test kelas eksperimen sebesar 77,87, dengan standar deviasi 7,18. Rata-rata hasil belajar mahasiswa pree-tes untuk kelas kontrol diperoleh 74,27dengan standar deviasi 7,02. Sedangkan posttes rata-rata hasil belajar mahasiswa kelas eksperimen diperoleh 84, 67 dengan standar deviasi 7,51 dan rata-rata hasil belajar mahasiswa kelas kontrol diperoleh 80,93 dengan standar deviasi 5,43. Terdapat perbedaan yang signifikan hasil belajar mahasiswa pada mata kuliah pengantar teknologi informasi antara kelompok yang diberi perlakuan menggunakan metode konvensional dengan kelompok yang diberi perlakuan dengan menggunakan E-Learning pada program studi Informatika Fakultas Ilmu Komputer Universitas Dehasen Bengkulu.

Kata Kunci,: Pengaruh E-Learning, Hasil Belajar

\section{Pendahuluan}

Seiring dengan perkembangan TIK dan globalisasi, interaksi dan penyampaian informasi berlangsung cepat. Perkembangan teknologi informasi dan komunikasi membawa dampak yang besar bagi kemajuan dunia pendidikan. Seiring dengan perkembangan tersebut metode pembelajaran juga mengalami perkembangan, baik pembelajaran secara personal, media pembelajaran serta proses pembelajaran. Bentuk dari perkembangan teknologi informasi yang diterapkan di dunia pendidikan adalah penggunaan e-learning.

E-learning merupakan inovasi dalam sebuah metode pembelajaran yang mempunyai kontribusi yang besar terhadap perubahan proses pembelajaran, proses belajar tidak lagi hanya mendengarkan uraian materi dari dosen, akan tetapi mahasiswa juga dapat melakukan aktivitas lain seperti mengamati, melakukan, mendemonstrasikan dan lain-lain. Materi ajar dapat divisualisasikan dalam format dan bentuk yang lebih dinamis dan interaktif sehingga learner akan 
termotivasi untuk terlibat lebih jauh dalam proses pembelajaran tersebut.

Saat ini, proses pembelajaran yang berlangsung di program studi Informatika Fakultas Ilmu Komputer Universitas Dehasen Bengkulu masih berupa pembelajaran konvensional. Pembelajaran konvensional yang dimaksud adalah proses pembelajaran yang penyampaiannya di uraikan langsung dari dosen dengan menggunakan media yang standar, seperti power point atau buku kemudian memberikan penugasan kepada mahasiswa.

Fasilitas internet yang ada di Universitas Dehasen Bengkulu sudah cukup memadai. Penggunaan internet ini tidak terbatas untuk dosen dan pegawai, tetapi juga untuk kebutuhan mahasiswa. Namun demikian penggunaan internet sebagai sumber belajar belum dimaksimalkan. Universitas Dehasen Bengkulu sendiri sudah memiliki e-learning, namun penggunaannya belum optimal oleh dosen dan mahasiswa. Dengan adanya media pembelajaran e-learning ini, diharapkan dapat membantu proses pembelajaran menjadi lebih kondusif, meningkatkan minat belajar mahasiswa, serta dapat meningkatan proses belajar mahasiswa dan diharapkan dapat meningkatkan hasil belajar. Hal ini dikarenakan elearning menuntut peserta didik untuk bisa berinteraksi dengan internet, seperti mengakses informasi yang luas, memunculkan keaktifan mahasiswa yang disebabkan tantangan, serta ketersediaan materi untuk pembelajaran. Elearning adalah proses pembelajaran jarak jauh yang menggunakan jaringan internet untuk menyampaikan materi kuliah kepada mahasiswa, sehingga pembelajaran dapat berlangsung tanpa terbatas ruang dan waktu.

Penelitian ini mengkaji pemanfaatan media pembelajaran e-learning di Program Studi Informatika pada mata kuliah Pengantar Teknologi Informasi sebagai sumber belajar untuk meningkatkan hasil belajar mahasiswa, sehingga peran dosen sebagai fasilitator dapat dilaksanakan. Selain itu, keaktifan mahasiswa akan lebih ditekankan ketika menggunakan media pembelajaran e-learning karena langkah pembelajaran ini telah diberikan, sehingga akan menciptakan budaya belajar menuntut mahasiswa untuk mandiri dengan harapan mampu meningkatkan pemahaman mahasiswa terhadap materi dan pada akhirnya meningkatnya hasil belajar mahasiswa tersebut.

Menanggapi permasalahan yang ada, maka seorang pendidik seharusnya menjadi ujung tombak dalam penyelenggaraan pendidikan mengikatkan upayanya dalam penyelesaian masalah yang ada. Upaya yang dapat dilakukan salah satunya yaitu dengan memperbaiki model pembelajaran yang diterapkan pada proses pembelajaran tersebut, karena model pembelajaran juga merupakan faktor pendukung dari keberhasilan peserta didik dalam belajar. Oleh karena itu hendaknya seorang dosen dapat menguasai dan memiliki metode pengajaran yang cocok dengan topik yang akan diajarkan sehingga dapat mencapai tujuan yang diharapkan secara maksimal.

Perubahan paradigma instructional based learning menjadi constructional based learning membuat para pendidik (guru atau dosen) harus mendesain pembelajaran yang mengaktifkan peserta didik untuk lebih banyak mengasah skill dengan praktik mandiri. Untuk mewujudkan proses pembelajaran yang efektif, inovatif, dan menyenangkan yang dapat mengaktifkan peserta didik, maka pendidik dapat memanfaatkan semua sumber daya yang ada di sekolah, baik sumber daya manusia, sarana dan prasarana, dan sumber daya yang lain untuk membuat pembelajaran lebih efektif, inovatif, dan menyenangkan. E-learning adalah proses pembelajaran yang fleksibel, nyaman, dan kemudahan bagi peserta didik untuk belajar dimanapun tanpa harus berada di tempat yang sama. Keuntungan lain dari e-learning adalah kemampuan peserta didik untuk beradaptasi dan berkomunikasi dengan teman-teman sebayanya tanpa terbatas ruang dan jarak.

Berdasarkan uraian yang telah disebutkan di atas, mendorong peneliti untuk melakukan penelitian dengan judul Pengaruh Penerapan E-Learning Terhadap Hasil Belajar Mahasiswa Informatika Universitas Dehasen Bengkulu. Rumusan masalah dalam penelitian ini yaitu : Apakah pembelajaran e-learning berpengaruh terhadap hasil belajar mahasiswa Prodi Informatika Fakultas Ilmu Komputer Universitas Dehasen Bengkulu.

\section{TinJAUAN PUSTAKa}

\section{A. Belajar dan Pembelajaran}

Belajar adalah suatu kegiatan yang tidak terpisahkan dari kehidupan manusia. Dengan belajar manusia dapat mengembangkan potensi-potensi yang ada pada dirinya, sehingga nantinya mampu menyesuaikan diri demi pemenuhan kebutuhan.

Belajar adalah suatu proses yang komplek yang terjadi pada diri setiap orang sepanjang hidupnya. Proses belajar terjadi karena adanya interaksi seseorang dengan lingkungannya. Oleh karena itu, belajar dapat terjadi dimana saja dan kapan saja. Interaksi ini membentuk pengalaman belajar yang juga akan berpengaruh terhadap pembentukan kemampuan [1].

Belajar adalah segenap rangkaian kegiatan atau aktivitas yang dilakukan secara sadar oleh seseorang yang mengakibatkan adanya perubahan dalam dirinya berupa penambahan pengetahuan atau kemahiran berdasarkan alat indra dan pemahamannya. Oleh sebab itu, apabila setelah belajar peserta didik tidak ada perubahan tingkah laku yang positif dalam arti tidak memiliki kecakapan baru serta wawasan pengetahuannya tidak bertambah, maka dapat dikatakan bahwa belajarnya belum sempurna [2].

Belajar adalah berubah. Dalam hal ini yang dimaksudkan belajar berarti usaha mengubah tingkah laku. Jadi belajar akan membawa suatu perubahan pada individu-individu yang belajar. Perubahan tidak hanya berkaitan dengan penambahan ilmu pengetahuan, tetapi juga bentuk kecakapan, keterampilan, sikap, pengertian, harga diri, minat, watak, penyesuaian diri. Intinya menyangkut segala aspek organisme dan tingkah laku pribadi seseorang [3]. 
Dari pengertian di atas, maka dapat disimpulkan bahwa belajar dapat dimaknai sebagai suatu proses untuk memperoleh perubahan tingkah laku dari serangkain kegiatan misalnya dengan membaca, mengamati, mendengarkan, meniru dan lain sebagainya serta hasil pengalamannya dalam interaksi dengan lingkungannya.

Pembelajaran adalah serangkaian kegiatan yang melibatkan informasi dan lingkungan yang disusun secara terencana untuk memudahkan siswa dalam belajar [4]. Lingkungan yang dimaksud tidak hanya berupa tempat ketika pembelajaran itu berlangsung, tetapi juga metode, media, dan peralatan yang diperlukan untuk menyampaikan informasi. Proses mengajar merupakan penyampaian informasi dari fasilitator pengetahuan kepada akseptornya. Selain sebagai penyampai informasi kepada siswa, fasilitator pembelajaran juga sebagai pengatur proses pembelajaran dan lingkungan di dalam kelas. Proses belajar dipengaruhi oleh faktor-faktor internal dan eksternal. Faktor internal seperti sikap, pandangan hidup, perasaan senang dan tidak senang, kebiasaan dan pengalaman pada diri peserta didik. Faktor eksternal merupakan rangsangan dari luar diri siswa melalui indera yang dimilikinya, terutama pendengaran dan penglihatan.

Pembelajaran merupakan suatu sistem yang bertujuan untuk membantu proses belajar peserta didik. Pembelajaran berupa serangkaian peristiwa yang dirancang, disusun sedemikian rupa untuk memengaruhi dan mendukung terjadinya proses belajar peserta didik yang bersifat internal. Situasi atau kondisi dalam pembelajaran yang memungkinkan terjadinya proses belajar harus dirancang. Dalam proses pembelajaran, kedudukan pendidik sudah tidak dapat lagi dipandang sebagai penguasa tunggal, tetapi dianggap sebagai manager of learning (pengelola belajar) yang perlu senantiasa siap membimbing dan membantu para peserta didik [5]. Simpulan dari pengertian proses pembelajaran menurut para ahli diatas adalah merupakan serangkaian kegiatan yang berfungsi untuk memudahkan peserta didik dalam belajar, yang tidak hanya melibatkan lingkungan tempat yang digunakan tetapi juga melibatkan metode, media, dan peralatan yang diperlukan untuk menyampaikan informasi.

Pemilihan metode pembelajaran yang tepat bagi seorang pendidik harus mempertimbangkan prinsip-prinsip penggunaan metode yang digunakan. Secara umum prinsip penggunaan metode yang dipilih harus: (1) memperhatikan minta, kesiapan, kemampuan dan dorongan peserta didik dalam mengikuti pelajaran, (2) menumbuhkan kemampuan berpikir dan berkreatifitas secara bebas tidak ada tekanan dan paksaan dalam mengikuti pelajaran, (3) menumbuhkan rasa senang dan keinginan untuk melakukan aktivitas dalam proses pembelajaran, (4) menumbuhkan rasa tanggung jawab dan oercaya diri dengan landasan kemandirian, dan (5) memperhitungkan sarana dan alat bantu media pembelajaran yang digunakan [2].

\section{B. Media Pembelajaran}

Media pembelajaran memiliki peranan yang sangat penting dalam menunjang kualitas proses belajar mengajar, sehingga interaksi belajar mengajar dapat menjadi lebih efektif dan juga dapat membuat pembelajaran lebih menarik dan menyenangkan. Salah satu media pembelajaran yang sedang berkembang saat ini adalah media audiovisual. Perkembangan media pembelajaran saat ini, akan searah dengan berkembangnya teknologi. Semula media pembelajaran muncul dari yang paling tua yaitu percetakan mekanis, kemudian lahir teknologi audiovisual dengan penggabungan mekanis dan elektronis. Media audiovisual terdiri dari dua kata yaitu audio dan visual. Audio berarti pendengaran atau dapat didengar, sedangkan visual yaitu yang nampak diliat oleh mata atau yang kelihatan [6].

Perbedaan pembelajaran tradisional dengan e-learning yaitu kelas tradisional, dosen atau guru dianggap sebagai orang yang serba tahu dan ditugaskan untuk menyalurkan ilmu pengetahuan kepada pelajarnya. Sedangkan di dalam pembelajaran e-learning fokus utamanya adalah mahasiswa. Mahasiswa mandiri pada waktu tertentu dan bertanggungjawab untuk pembelajarannya. Suasana pembelajaran $e$ learning akan memaksa mahasiswa memainkan peranan yang lebih aktif dalam pembelajarannya. Mahasiswa membuat desain dan mencari materi dengan usaha, dan inisiatif sendiri.

Karakteristik e-learning antara lain adalah : Memanfaatkan jasa teknologi elektronik; dimana pendidik dan peserta didik, peserta didik dan sesama peserta didik atau pendidik dan sesama pendidik dapat berkomunikasi dengan relatif mudah dengan tanpa dibatasi oleh hal-hal yang protokelor; Menggunakan bahan ajar bersifat mandiri (self learning materials) disimpan di komputer sehinga dapat diakses oleh pendidik dan peserta didik kapan saja dan dimana saja dan yang bersangkutan memerlukanya; dan Memanfaatkan jadwal pembelajaran, kurikulum, hasil kemajuan belajar dan hal-hal yang berkaitan dengan administrasi pendidikan dapat dilihat setiap saat [7].

Pengertian sederhana dari e-learning adalah akses online kepada sumber belajar dimana saja dan kapan saja. Elearning menawarkan kesempatan baru kepada pengajar dan pebelajar untuk memperkaya pengalaman belajar mengajar melalui lingkungan maya (virtual) yang mendukung bukan hanya penyampaian materi namun juga penggalian dan aplikasi dari informasi serta pemahaman terhadap pengetahuan baru.

Pengunaan e-learning untuk pembelajaran jarak jauh telah banyak digunakan. Adapun kelebihan proses pembelajaran menggunakan elearning yaitu : (1) Meningkatkan interaksi pembelajaran (encbance interactif), yaitu pembelajaran yang dirancang dan dilaksanakan secara cermat dapat meningkatkan kadar interaksi pembelajar antara pembelajar dengan materi pembelajar, pembelajar dengan pengajar, dan dengan pembelajar dengan pembelajar lainnya. (2) Mempermudah interaksi pembelajaran dari mana dan kapan saja (time and placeflexibility), yaitu pembelajar dapat melakukan interaksi dengan sumber belajar kapan saja sesuai 
dengan ketersediaan waktunya dan dimanapun dia berada. (3) Memiliki jangkauan yang luas (potential to reacb a global audience), yaitu pembelajaran yang fleksibel dari segi waktu dan tempat, menjadikan jumlah pembelajar yang dapat dijangkau kegiatan pembelajaran melalu e-learning semakin banyak dan terbuka secara luas bagi siapa saja yang membutuhkannya. (4) Mempermudah penyempurnaan dan penyimpanan materi pembelajaran (easy updating of content as well as archivable capabilities), yaitu fasilitas yang tersedia dalam teknologi e-learning turut membantu mempermudah pengembangan materi pembelajaran elektronik [6].

Pembangunan dan pengembangan e-learning saat ini begitu mudahnya dengan perangkat lunak Learning Management System (LMS) yang disebut moodle. Fitur-fitur penting penunjang pembelajaran tersebut misalnya tugas, quiz, komunikasi, kolaborasi, serta fitur utama yang dapat mengupload berbagai format materi pembelajaran [8]. Pendidik dituntut untuk menciptakan suasana belajar yang efektif, inovatif, dan menyenangkan. Dalam proses pembelajaran, pendidik berperan sebagai motivator dan fasilitator.

\section{Hasil Belajar}

Hasil belajar merupakan suatu hasil yang telah dicapai individu dalam melakukan kegiatan atau usaha untuk memperoleh perubahan tingkah laku dari serangkaian kegiatan misalnya dengan membaca, mengamati, mendengarkan, meniru dan lain sebagainya serta hasil pengalamannya dalam interaksi dengan lingkungannya. Defenisi hasil belajar adalah sejumlah pengalaman yang diperoleh peserta didik yang mencakup ranah kognitif, afektif, dan psikomotorik [9]. Belajar tidak hanya penguasaan konsep teori materi pelajaran saja, tetapi juga penguasaan kebiasaan, persepsi, kesenangan, minat-bakat, penyesuaian sosial, macam-macam keterampilan, cita-cita, keinginan dan harapan. Hasil belajar adalah kemampuan yang dimiliki siswa setelah ia menerima pengalaman belajarnya. Setelah suatu proses belajar berakhir, maka siswa memperoleh suatu hasil belajar. Hasil belajar mempunyai peranan penting dalam proses pembelajaran. Tujuan utama yang ingin dicapai dalam kegiatan pembelajaran adalah hasil belajar.

Hasil belajar adalah pola-pola perbuatan, nilai-nilai, pengetahuan-pengetahuan, sikap, apresiasi, abilitas, dan keterampilan [10]. Hasil belajar merupakan hasil dari suatu interaksi tindak belajar dan tindak mengajar. Dari sisi guru, tindak mengajar diakhiri dengan proses evaluasi hasil belajar. Dari sisi siswa, hasil belajar merupakan berakhirnya pengajaran dari puncak proses belajar [11]. Hasil belajar pada dasarnya, merupakan hasil interaksi dari berbagai faktor yang mempegaruhi proses secara keseluruhan. Faktor-faktor yang berinteraksi tersebut berbeda antara satu individu dengan individu lainya. Faktor yang mempengaruhi hasil belajar siswa dapat dibagi menjadi dua yaitu: faktor intrinsik (dalam) dan faktor ekstrinsik (luar). Faktor yang ada dalam diri siswa berupa sikap kondisi fisik, psikologi, perkembangan kognitif, bakat dan motivasi, sedangkan faktor yang mempegaruhi dari luar adalah: keadaan lingkungan, fasilitas, kemampuan mengajar guru, materi pelajaran dan lainya.

Menurut Benjamin S. Bloom dalam bukunya Taxonomy of educatonal Objectivest telah memilah ranah (domain) hasil belajar kedalam tiga ranah utama yaitu ranah kognitif (cognitif domain), ranah afektif (afektif domain), dan ranah psikomotor. Ketiga tingkatakan itu dikenal dengan istilah Bloom's Taxonomy (Taksonomi Bloom). Ranah kognitif meliputi kemampuan pengembangan keterampilan intelektual (knowledge) dengan tingkatan-tingkatan yaitu : 1 . Hapalan (C1), merupakan kemampuan menyatakan kembali fakta, konsep prinsip, prosedur atau istilah yang telah dipelajarinya. 2. Pemahaman (C2), merupakan kemampuan untuk memahami arti, interpolasi, interpretasi intruksi (pengarahan) dan masalah. 3. Penerapan (C3), merupakan kemampuan untuk menggunakan konsep dalam situasi baru atau pada situasi konkret. Kemampuan yang diperoleh berupa kemampuan untuk menerapkan prinsip, konsep, teori, hukum maupun metode yang dipelajarinya dalam situasi baru. 4 . Analisis (C4), analisis adalah usaha untuk memilah suatu integritas menjadi unsur-unsur atau bagian-bagian sehingga jelas heirarkinya dan atau susunannya. 5. Sintesis (C5), berpikir sintesis merupakan berpikir divergen.Sintesis merupakan kemampuan menggabungkan unsur-unsur sehingga terjelma pola yang berkaitan secara logis atau mengambil kesimpulan dari peristiwa-peristiwa yang ada hubungannya satu dengan yang lain. 6. Evaluasi (C6), evaluasi adalah pemberian keputusan tentang nilai sesuatu yang mungkin dilihat dari segi tujuan, gagasan, cara kerja, materi dan kriteria tertentu.

\section{Metode Penelitian}

Penelitian ini adalah jenis penelitian eksperimen. Dikatakan eksperimen karena peneliti ingin memanipulasi variabel dengan memberikan perlakuan pada dua kelas. Mengingat taraf tercapainya syarat penelitian eksperimen tidak memenuhi karena banyaknya variabel lain yang tidak bisa dikontrol, maka penelitian ini dikategorikan penelitian eksperimen semu (quasi experiment) yaitu perlakuan diberikan untuk menentukan pengaruhnya pada variabel terikat, tetapi variabel-variabel yang berpengaruh tidak dapat dikontrol dengan ketat.

Sampel dalam penelitian ini adalah mahasiswa semester I Prodi Informatika Fakultas Ilmu Komputer Universitas Dehasen Bengkulu, terdiri dari 2 kelas dengan jumlah 60 orang mahasiswa, 2 kelas itu akan dibagi menjadi 1 kelas eksperimen dan 1 kelas kontrol. Pengambilan sampel dilakukan dengan mengambil seluruh populasi yang ada (total sampling).

Tabel I.

\begin{tabular}{|l|l|l|l|}
\hline \multicolumn{1}{|c|}{ Metode Pree Test dan Post Test } \\
\hline Kelas & \multicolumn{1}{c|}{ Metode } & Pre Test & Post Test \\
\hline Konsperimen & Elearning & Elearning & Elearning \\
\hline
\end{tabular}


Dari tabel I di atas, pengujian pree test dan post test kelas eksprimen menggunakan media e-learning (online), sedangkan untuk pree test dan post test kelas kontrol menggunakan media kertas (manual) sebagai media pengujiannya.

Tipe pengumpulan data yang dilakukan dalam penelitian ini adalah : Teknik tes pengetahuan digunakan untuk mengetahui hasil belajar mahasiswa untuk mata kuliah pengetahuan komputer. Butir-butir pertanyaan dalam tes ini disusun dalam bentuk pilihan ganda dengan kriteria penilaian, jika jawaban benar diberi nilai 1 dan jika salah diberi nilai 0. Pelaksanaan teknik tes ini dilakukan dua kali pada tiap kelompok, yaitu tes awal (pree-tes) dan tes akhir (post-test). Teknik Dokumentasi digunakan untuk mencari dan mengumpulkan data terkait dengan dokumen yang relevan dalam penelitian ini antara lain : dokumentasi kategori kriteria ketuntasan minimal, nama mahasiswa dan nilai prestasi belajar mahasiswa dalam pelajaran Pengantar Teknologi Informasi (PTI).

Analisis Data menggunakan Analisis Statistik Deskriptif, Analisis Inferensial dan Uji Signifikansi. Analisis Statistik Deskriptif digunakan untuk mendeskripsikan karakteristik skor dari sampel penelitian. Dalam hal ini digunakan skor minimum dan maksimum, urutan gejala pusat (rata-rata, median, modus), standar deviasi, tabel distribusi dan histogram.

\section{HASIL DAN PEMBAHASAN}

Data yang diperoleh dalam penelitian ini adalah data yang diperoleh dari hasil hasil tes pilihan ganda yang terdiri dari pree-test dan pos-test pada kelas eksperimen dan kelas kontrol. Data yang diperoleh kemudian dianalisis secara deskriptif.

\section{A. Hasil pre-test}

Pree-test yang dilakukan sebelum penerapan pembelajaran E-Learning dalam mata kuliah Pengantar Teknologi Informasi (PTI) perlu dilakukan untuk mengetahui kemampuan awal mahasiswa pada materi sistem komputer dalam bentuk tes pilihan ganda sebanyak 25 soal diperoleh hasil sebagai berikut.

Tabel II.

Data Distribusi Frekuensi Nilai Pree-test Kelas Eksperimen

\begin{tabular}{|c|c|c|c|}
\hline Predikat & Nilai & Prekuensi & Persentase \\
\hline A & $80-100$ & 1 & 3,3 \\
\hline B & $70-79$ & 14 & 46,7 \\
\hline C & $60-69$ & 12 & 40 \\
\hline D & $50-59$ & 3 & 10 \\
\hline E & $<50$ & 0 & 0 \\
\hline \multicolumn{2}{|c|}{ Jumlah } & 30 & 100 \\
\hline
\end{tabular}

Pree-test kelas eksperimen dijadikan sebagai pembanding sebelum penerapan pembelajaran E-Learning, hasil pree-test kelas eksperimen didapat setelah melakukan tes pilihan ganda tentang mata kuliah Pengantar Teknologi Informasi (PTI) sebanyak 25 soal.

Hasil pree-test kelas eksperimen menunjukkan bahwa dari 30 mahasiswa terdapat 1 orang yang mendapat predikat kelulusan yang tinggi, 14 mahasiswa atau $47 \%$ yang telah memenuhi standar kelulusan, dan 15 mahasiswa atau 50\% berada pada kelulusan rata-rata, serta tidak ada mahasiswa yang mendapat nilai dibawah 60 .

Tabel III.

Data Distribusi Frekuensi Nilai Pree-Test Kelas Kontrol

\begin{tabular}{|c|c|c|c|}
\hline Predikat & Nilai & Prekuensi & Persentase \\
\hline A & $80-100$ & 0 & 0 \\
\hline B & $70-79$ & 8 & 26,7 \\
\hline C & $60-69$ & 15 & 50,0 \\
\hline D & $50-59$ & 5 & 16,7 \\
\hline E & $<50$ & 2 & 6,7 \\
\hline \multicolumn{2}{|c|}{ Jumlah } & 30 & 100 \\
\hline
\end{tabular}

Pree-test kelas kontrol dilakukan sebagai pembanding sebelum penerapan model pembelajaran yang lain, hasil pree-test kelas kontrol di dapat setelah melakukan tes pilihan ganda pada mata kuliah pengetahuan komputer sebanyak 25 soal.

Hasil pree-test kelas Kontrol menunjukkan bahwa dari 30 mahasiswa terdapat 8 mahasiswa atau $26,7 \%$ yang memenuhi standar kelulusan, 15 mahasiswa atau $50 \%$ berada pada kelulusan rata-rata, 5 mahasiswa atau $16,7 \%$ masih belum lulus dan 2 mahasiswa mendapat nilai dibawah 60 .

\section{B. Hasil Post-test}

Post-test yang dilakukan di akhir pertemuan dalam pembelajaran Pengantar Teknologi Informasi (PTI) perlu dilakukan untuk mengetahui kemampuan mahasiswa pada materi sistem komputer dalam bentuk tes pilihan ganda sebanyak 25 soal diperoleh hasil sebagai berikut.

Tabel IV.

Data Distribusi Frekuensi Nilai Post-Test Kelas Eksperimen

\begin{tabular}{|c|c|c|c|}
\hline Predikat & Nilai & Prekuensi & Persentase \\
\hline A & $80-100$ & 6 & 20 \\
\hline B & $70-79$ & 19 & 63,3 \\
\hline C & $60-69$ & 5 & 16,7 \\
\hline D & $50-59$ & 0 & 0 \\
\hline E & $<50$ & 0 & 0 \\
\hline \multicolumn{2}{|c|}{ Jumlah } & 30 & 100 \\
\hline
\end{tabular}

Post-test kelas eksperimen dilakukan untuk mengetahui peningkatan prestasi belajar melalui penerapan pembelajaran E-Learning, hasil post-test di dapat setelah melakukan tes pilihan ganda tentang sistem komputer sebanyak 25 soal dan diperoleh hasil sebagai berikut.

Hasil post-test kelas eksperimen menunjukkan bahwa dari 30 mahasiswa terdapat 6 orang atau $20 \%$ yang mencapai tingkat kelulusan sangat istimewa, terdapat 19 orang atau $63,3 \%$ yang mencapai kelulusan istimewa, terdapat 5 orang atau $16,7 \%$ yang mencapai batas kelulusan minimal. 
Tabel V

Data Distribusi Frekuensi Nilai Post-Test Kelas Kontrol

\begin{tabular}{|c|c|c|c|}
\hline Predikat & Nilai & Prekuensi & Persentase \\
\hline A & $80-100$ & 1 & 3,3 \\
\hline B & $70-79$ & 17 & 56,7 \\
\hline $\mathrm{C}$ & $60-69$ & 11 & 36,7 \\
\hline $\mathrm{D}$ & $50-59$ & 1 & 3,3 \\
\hline $\mathrm{E}$ & $<50$ & 0 & 0 \\
\hline \multicolumn{2}{|c|}{ Jumlah } & 30 & 100 \\
\hline
\end{tabular}

Post-test kelas kontrol dilakukan untuk mengetahui peningkatan prestasi belajar melalui penerapan model pembelajaran konvensional, hasil post-test di dapat setelah melakukan tes pilihan ganda tentang mata kuliah Pengantar Teknologi Informasi (PTI) materi sistem komputer sebanyak 25 soal dan diperoleh hasil sebagai berikut.

Hasil post-test kelas kontrol menunjukkan bahwa dari 30 Mahasiswa terdapat 1 orang atau 3,3\% yang mencapai tingkat kelulusan sangat istimewa, terdapat 17 orang atau $56,7 \%$ yang mencapai kelulusan istimewa, terdapat 12 orang atau $40 \%$ yang mencapai batas kelulusan minimal.

\section{Perbandingan Nilai Post-test}

Analisis statistik deskriptif hasil post-test setelah penerapan pembelajaran E-Learning dalam pembelajaran Pengantar Teknologi Informasi (PTI) menjelaskan tentang perbandingan nilai post-test kelas eksperimen dan nilai posttest kelas control yang dihitung dengan bantuan Program Excell for Windows.

Perbandingan nilai dari hasil post-test kelas eksperimen dan kelas kontrol dengan penerapan pembelajaran $E$ Learning pada kelas eksperimen dan metode konvensional pada kelas kontrol. Jumlah mahasiswa pada kelas eksperimen adalah 30 mahasiswa dan 30 mahasiswa untuk kelas kontrol, dengan skor ideal 100. Skor terendah kelas eksperimen 72 dan 68 untuk kelas kontrol, skor tertinggi untuk kelas eksperimen dan kelas kontrol yaitu 100 dan 92, kemudian mean untuk kelas eksperimen 84, 67 sedangkan kelas kontrol 80,93, dan modus kelas eksperimen dan kontrol yaitu 80 , serta median kelas eksperimen dan Kontrol yaitu 84 dan 80 , dengan standar deviasi kelas eksperimen 7,508 dan kelas kontrol 5,43.

\section{Perbandingan Nilai Pree-test}

Analisis statistik deskriptif hasil pre-test sebelum penerapan pembelajaran E-Learning dalam pembelajaran Pengantar Teknologi Informasi (PTI) yang dihitung dengan bantuan Program Aplikasi Microsoft Office Excell for Windows.

Perbandingan nilai hasil pree-test kelas eksperimen dan kelas kontrol dengan penerapan pembelajaran E- Learning untuk kelas eksperimen dan metode konvensional untuk kelas kontrol menunjukkan bahwa dari jumlah mahasiswa pada kelas eksperimen adalah 30 mahasiswa dan 30 mahasiswa untuk kelas kontrol, dengan skor ideal 100 diperoleh skor tertinggi untuk kelas eksperimen yaitu 92 dan 84 untuk kelas kontrol, sedangkan untuk skor terendah untuk kelas eksperimen dan kontrol yaitu 64 dan 56, Mean untuk kelas eksperimen 77,87 sedangkan kelas kontrol 74,27, dan modus kelas eksperimen dan kelas kontrol adalah 80 dan 76, serta median kelas eksperimen dan kontrol yaitu 78, dan 76 dengan standar deviasi kelas eksperimen 7,18 dan kelas kontrol 7,02.

Melihat perbedaan diatas menunjukkan skor hasil preetest dan post-test mahasiswa, pree-test dilakukan sebelum penerapan pembelajaran E-Learning dan post-test dilakukan setelah penerapan pembelajaran E-Learning, hasilnya menunjukkan perubahan yang berbeda antara kelas eksperimen dan kelas kontrol. Kelas eksperimen mengalami peningkatan yang lebih signifikan dapat dilihat dari rata-rata nilai yang didapatkan, nilai rata-rata pre-test kelas eksperimen yaitu 77,87 setelah penerapan E-Learning mengalami peningkatan dengan nilai rata-rata post-test kelas eksperimen adalah 84,67. Meskipun kelas kontrol mengalami peningkatan nilai rata-rata pre-test dari 74,27 menjadi 80,93 setelah penerapan E-Learning tetapi peningkatannya tidak terlalu signifikan.

Tabel. VI

Perbandingan Nilai kelas Kontrol dan Eksperimen

\begin{tabular}{|c|c|c|c|c|c|}
\hline No & Tes & Tertinggi & Terendah & $\begin{array}{c}\text { Rata- } \\
\text { rata }\end{array}$ & $\begin{array}{l}\text { Standar } \\
\text { Deviasi }\end{array}$ \\
\hline 1 & $\begin{array}{l}\text { Pree Test } \\
\text { Kelas } \\
\text { Eksperimen }\end{array}$ & 92 & 64 & 77,87 & 7,18 \\
\hline 2 & $\begin{array}{l}\text { Pree Test } \\
\text { Kelas } \\
\text { Kontrol }\end{array}$ & 84 & 56 & 74,27 & 7,02 \\
\hline 3 & $\begin{array}{l}\text { Post Test } \\
\text { Kelas } \\
\text { Eksperimen } \\
\end{array}$ & 100 & 72 & 84,67 & 7,51 \\
\hline 4 & $\begin{array}{ll}\text { Post } & \text { Test } \\
\text { Kelas } & \\
\text { Kontrol } & \\
\end{array}$ & 92 & 68 & 80,93 & 5,43 \\
\hline
\end{tabular}

\section{KESIMPULAN}

Berdasarkan hasil penelitian yang telah dilakukan, maka dapat disimpulkan bahwa terdapat Pengaruh penggunaan media pembelajaran E-Learning lebih tinggi dibandingkan dengan menggunakan media pembelajaran konvensional dan prestasi belajar mahasiswa juga mengalami peningkatan yang cukup signifikan setelah menerapkan e-learning dalam pembelajaran Pengantar Teknologi Informasi (PTI), hal ini tergambar dari perbandingan hasil tes antara kelas eksperimen dengan penerapan e-learning dan kelas kontrol yang menggunakan metode konvensional (tradisional). Hasil rata-rata pree test kelas eksprimen 77,87 dan hasil pree test kelas kontrol 74,27. Sedangkan untuk hasil post tes juga menunjukkan bahwa kelas eksperimen lebih tinggi dibandingkan dengan kelas control, dimana nilai rata-rata hasil post test eksperimen 84,67 sedangkan untuk kelas kontrol rata-rata hasil post test 80,93. Dari hasil pree test dan post test yang didapat, sehingga dapat disimpulkan bahwa 
penerapan pembelajaran berbasis e-learning berpengaruh terhadap hasil belajar mahasiswa

\section{DAFTAR PUSTAKA}

[1] Pujiriyanto, Teknologi untuk Pengembangan Media dan Pembelajaran. Yogyakarta: UNY Press, 2012.

[2] Maswan and Muslimin Khairul, Teknologi Pendidikan. Yogyakarta Pustaka Pelajar, 2011.

[3] Sardiman A, Interaksi dan Motivasi Belajar-Mengajar. Jakarta: PT Rajagrafindo Persada, 2011.

[4] Suprihatiningrum Jamil, Trategi Pembelajaran : Teori dan Aplikasi. Yogyakarta: Ar-Ruzz Media, 2014.

[5] Ihsana El Khuloqo, Belajar dan Pembelajaran : Konsep Dasar Metode dan Aplikasi Nilai-Nilai Spiritualitas dalam Proses Pembelajaran. Yogyakarta: Pustaka Pelajar, 2017.

[6] Munir, Pembelajaran Jarak Jauh Berbasis Teknologi Informasi dan Komunikasi. Jakarta: Alfabeta, 2009.

[7] Munadi Yudhi, Media Pembelajaran (Sebuah Pendekatan Baru). Jakarta: Referensi (GP Press Group), 2013.

[8] Herman Dwi Surjono, Membangun Course E-Learning Berbasis Moodle. Yogyakarta: UNY Press, 2013.

[9] Rusman, Model-Model Pembelajaran. Jakarta: PT. Raja Grafindo Persada, 2013.

[10] Hamalik Oemar, Proses Belajar Mengajar. Jakarta: Bumi Aksara, 2013.

[11] Dimyati and Mudjiono, Belajar dan Pembelajaran. Jakarta: PT. Rineka Cipta, 2014. 